\title{
Susceptibility of Some Ornamental Plants to Aphid Infestation and Effects on Plant Biochemical Components and Morphological Structures
}

\author{
Rania S Rashwan* \\ Plant Protection Dept, Fac of Agri, Ain Shams Univ, P.O. Box 68, Hadayek Shoubra 11241, Cairo, Egypt \\ * Corresponding author: raniarashwan@ymail.com
}

DOI:10.21608/ajs.2021.90748.1405

Received 14 August, 2021 ; Accepted 30 October, 2021

\author{
Keywords: \\ Ornamental plants, \\ Aphid Susceptibility, \\ Morphological \\ structure, \\ Biochemical \\ components
}

\begin{abstract}
Aphid is a major insect pest attacking ornamental plants. It causes great damage by reducing the economic values of plants. The investigated research aims to determine the relation between leaf biochemical components, morphological structures of plant leaf surface and the susceptibility of seven ornamental plants to Aphid Infestation. Highest recorded aphid infestation was observed on Tecoma stans during 2017 and 2018 seasons followed by Rosa damascena and Jasminum grandiflorum. There was no recorded infestation on four inspected ornamental plants, Ruta graveolens, Schefflera actinophylla, Nerium oleander and Bougainvillea spectabilis. Activity of antioxidant enzymes plays as defense line when increasing the insect population density. Biochemical components are varied among different plants that prevents or reduces insect infestation, as tannins, total phenol, and Phenol oxidase. Trichomes are considered as main morphological character in plant defense system. These results enhanced utilization resistant ornamental plants due to preventing aphid infestation. It is considered one of the integrated pest management programs, that achieves health environment without more insecticidal application.
\end{abstract}

\section{Introduction}

Aphid is considered one of the major economic insect pests attacking ornamental plants which is used in medical purposes and decoration. Aphid population could be increased to reach high density in a short time when ecological factors are favorable for developing insect. Aphids feed extra plant sap by mouth parts more than need. Feeding behavior led to secret a lot of sugary substance on plant leaves known as honeydew. It could be describing as a sticky substance accumulate on leaf surface and prevent plant breathing, it also effects on the potential of photosynthesis process. Aphid feeding also causes weakness of plant and may cause plant malformation (Mehrparvar et al 2008). It may stop growth leaf buds and prohibit plant flowering. Otherwise transmitting viruses by this economic insect pest (Khatab 2007).

Some biochemical plant components are considered the main factor in enhancing self-defense. That may protect plants from pest attacking, insect feeding and incomplete growth. Plants could produce toxic substances such as alkaloids, flavonoids, terpenoids, nthocyanins, and phenol which may kill insect or prevent developing. (Hanley et al 2007).

Specialized Reactive oxygen species (ROS) detoxifying enzymes, such as Glutathione $S$-transferase (GSTs) and Superoxide dismutase (SODs) play an important role in detoxifying the effect of biotic and abiotic stimulate which are considered the first line of ROS defense. Defense enzymes can eliminate or protect the cell from the damage caused by ROS. That fostering plant protection against oxidative stress 
(Marrs et al 1995, Torres 2010). Plants may also protect themselves from different pest attacking by presence of some morphological structures that may prevent insect feeding or laying eggs (Rani and Jyothsna 2010).

Host plant resistance is one of the important programs for integrated pest management which is safe alternative in pest controlling (Brzozowski and Mazourek 2020).

Therefore, the present research was carried to estimate the biochemical components and morphological structure of the plant leaves and its relation to aphid infestation as a utilized method in integrated pest management.

\section{Materials and Methods}

\subsection{Experimental area and design}

Experiments were conducted at the experimental farm attached to Taif governorate, Kingdom of Saudi Arabia. The experiments were carried out through 2017 and 2018 successive seasons. To study the susceptibility of ornamental plants to Aphid infestation, seven plants were chosen, namely: Tecoma stans (F: Bignoniaceae), Bougainvillea spectabilis (F: Nyctaginaceae), Nerium oleander (F: Apocynaceae), Schefflera actinophylla (F: Araliaceae), Rosa damascene (F: Rosaceae), Jasminum grandiflorum (F: Oleaceae), Ruta graveolens (F: Rutaceae). Seeds were sown on February $4^{\text {th }}$ for the two tested seasons. The experimental area was planted in equal pots (of about $30 * 25 \mathrm{~cm}$ ). Seven tested ornamentals were designed in complete randomized block. Pots of tested plants replicated three times. All experiments were free from chemical application during the experimental season.

\subsection{Monitoring the seasonal fluctuation of aphids}

To follow seasonal fluctuation of aphids, weekly samples were started after 15 days of sowing date and continued for 4 months. For recording the aphid's population density, samples of 10 plant leaves/ replicate (three replicates/cultivar) were chosen randomly and carefully examined early in the morning. Population density of aphids was determined by counting all individuals (nymphs and adults) and recorded by using 10X lenses in the experimental area.

\subsection{Biochemical assessment of plant leaves}

Samples of ten leaves of each tested plant were picked out during aphid population density recorded highest density during the season. Biochemical analysis was conducted in plant protection research Institute, Agricultural Research Center, Egypt. The plant samples were stored at $20^{\circ} \mathrm{C}$, according to the described method by Ni et al (2001).

\subsubsection{Nitrogen Determination}

The nitrogen in protein is converted to ammonium sulphate by $\mathrm{H}_{2} \mathrm{SO}_{4}$ during digestion. This salt, on steam-distillation, liberates ammonia which is collected in boric acid solution. It titrated against standard acid till recorded violet color (Moore and Stein1948).

\subsubsection{Inorganic Phosphorus (P) and Potassium determination}

Phosphorus determination could be determined as described by Rockstein and Herron (1951). The phosphate ion was detected using a commercial kit of Quimica Clinica aplicada phosphor reacts with molybdate to produce phosphor-molybdate. Finally, that reduced to a molybdenum blue which is photometrically measured at $650 \mathrm{~nm}$. Determination of Potassium was followed by the method described by Kelley (1946).

\subsubsection{Antioxidant Defense Enzymes Activity}

Plant leaves were grinding with sodium phosphate buffer at $\mathrm{pH} 6.5$ and centrifuged at $2000 \mathrm{rpm}$ for 10 min. The supernatant was used to measure the activity of Antioxidant Defense Enzymes. The enzyme activity was expressed as units /g of fresh weight/hour. Glutathione S-transferase and was estimated spectrophotometrically as described by Dean et al (1995), while Superoxide dismutase activity assayed following the method of McCord and Fridovich (1969).

\subsubsection{Proline}

Determination of proline content in plant samples was followed by the described method of Boctor (1971).

\subsubsection{Tannins}

Leave tissues $(50 \mathrm{mg})$ were mixed with $7.5 \mathrm{ml}$ of $\mathrm{H}_{2} \mathrm{O}$ at $100^{\circ} \mathrm{C}$ for half an hour. Mixture was centrifuged at $10,000 \times \mathrm{g}$ for twenty min. Estimating of tannins was described by Sadasivam and Manickam (1992). 


\subsubsection{Phenols}

Leave sample was washed with distilled water and dried in oven at $45^{\circ} \mathrm{C}$ for 4 days. Sample was crushed in an electric grinder into powder. Extraction was performed as described by Kâhkônen et al (1999).

\subsubsection{Total proteins}

Five hundred $\mathrm{mg}$ of the leaves sample was grinding in $5 \mathrm{ml}$ of $0.01 \mathrm{Mg}$ phosphate buffer $(\mathrm{pH}$ 7). Total proteins were estimated as mentioned of Bradford (1976). Protein reagent was prepared by dissolving $100 \mathrm{mg}$ of Coomassie Brilliant blue G250 in $50 \mathrm{ml} \mathrm{95 \%} \mathrm{ethanol.}$

\subsubsection{Total free amino acids}

Ninhydrin reagents were used to estimate total amino acids according to the method described by Lee and Takabashi (1966), Vartainan et al (1992). Plant Sample were grinding in ethanol (80\%). The mixture was heated in a boiling water bath $10 \mathrm{~min}$ and cooled in a tap water bath. It centrifuged at $2000 \mathrm{rpm}$ for ten minutes. Amount of total free amino acids was estimated by adding $1 \mathrm{ml}$ of supernatant and $1.9 \mathrm{ml}$ ninhydrin. Mixture was boiled, the bluish pink was read at $570 \mathrm{~nm}$.

\subsubsection{Total carbohydrates}

Total carbohydrates were measured in acid extract by the phenol-sulfuric acid reaction according to (Dubois et al 1956, Crompton and Birt (1967). Weight of $100 \mathrm{mg}$ of the plant sample was added into a boiling tube then adding $10 \mathrm{ml}$ of 2.5 N HCL It hydrolyzed by keeping in a boiling water bath for three hours, it left for cooling at room temperature

The absorbance of characteristic yelloworange color is measured at $490 \mathrm{~nm}$ against blank. Total carbohydrate is expressed as: $\mu \mathrm{g}$ glucose/gm fresh weight.

\subsection{Scanning electron microscope examination}

Sample of leaves was immediately kept in glutaraldehyde solution (2\%) at room temperature till preparation. Samples were washed several times with distilled water. Leaves were left at room temperature until dry. Pieces of leaves were cut with size 3 to $10 \mathrm{~mm}$. Samples were coated with gold to allow expectation and fixed on adhesive tab. Methodology of scanning was described by (Echlin 2009). Leaf samples were fixed with two side carbo tape. SEM Model Quanta 250 field emission gun (FEG)was used for inspection. Figures were captured at two magnification powers 500x and $1000 x$. Accelerating voltage of figures were $30 \mathrm{KV}$ and resolution for Gun.1n. Scanning electron microscope were utilized at Egyptian mineral resources authority, central laboratories sector.

\subsection{Statistical analysis}

Data analyzed by using SAS program (SAS 2001). ANOVA test was conducted to evaluate the significance among the seven tested ornamental plants by using LSD at $\mathrm{p}<0.05$. Correlation coefficient (r) level was estimated to determine the relation between the chemical components and aphid infestation on the tested plants.

\section{Results and Discussion}

3.1 Population fluctuations of aphids on seven ornamental plants during 2017 and 2018 seasons, susceptibility of ornamental plants to aphid infestations

Tabulated data in Table 1 showed distribution densities of aphid infestation in Taif Governorate on seven hosts of ornamental plants during 2017 and 2018 seasons. Weekly inspection started $19^{\text {th }}$ February till the end of June. Data shown that there is different appearance of aphid densities between three ornamental plants: Rosa damascena, Tecoma stans and Jasminum grandiflorum. No recorded infestation of aphids on four inspected ornamental plants, Ruta graveolens, Schefflera actinophylla, Nerium oleander and Bougainvillea spectabilis. Statistical analysis supported that there are significant differences between three infested plants according to their susceptibility to infestation. Calculated $\mathrm{F}$ values $=6.2$ and $12.4, \mathrm{LSD}=$ 36.9 and 42.3 for 2017 and 2018 seasons, respectively. Obtained results were confirmed with the finding of Rashwan et al (2016) who recorded no aphid infestation on the four ornamental plants: B. spectabilis, $N$. oleander, $S$. actinophylla and $R$. graveolens during $2015 / 2016$ season. The most abundant density of aphids for all tested plants was noticed during $20^{\text {th }}$

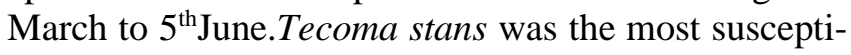
ble ones with mean number 144 and 145.8 individuals/leaflets in 2017 and 2018, respectively. $R$. damascena and $J$. grandiflorum were the lowest infested plants in two inspected seasons. Seasonal mean numbers of $R$. damascenae 18.6 and 21.5 individuals/leaflets for2017 and 2018, while for J. grandiflora recorded 11.6 and 12.5 individuals/leaflets during 2017 and 2018, respectively. Therefore, the three 
Table 1. Weekly number of aphids of the seven tested ornamental plants during 2017 and 2018 seasons at Taif Governorate

\begin{tabular}{|c|c|c|c|c|c|c|c|c|c|c|c|c|c|c|}
\hline \multirow{3}{*}{$\begin{array}{c}\text { Inspection } \\
\text { date }\end{array}$} & \multicolumn{14}{|c|}{ Mean number of aphids/leaflets } \\
\hline & \multicolumn{2}{|c|}{ 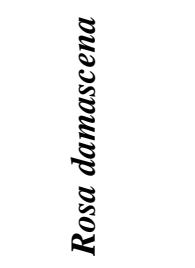 } & \multicolumn{2}{|c|}{ 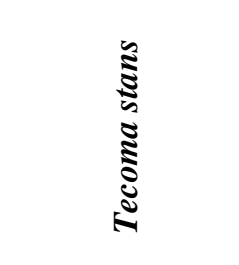 } & \multicolumn{2}{|c|}{ 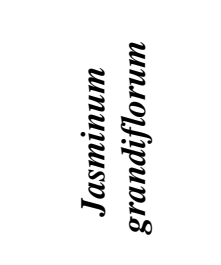 } & \multicolumn{2}{|c|}{ 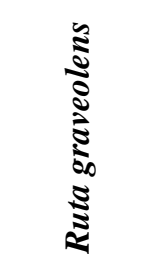 } & \multicolumn{2}{|c|}{ 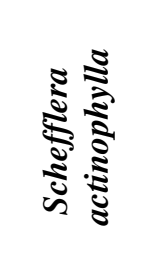 } & \multicolumn{2}{|c|}{ 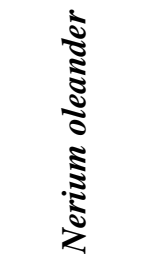 } & \multicolumn{2}{|c|}{ 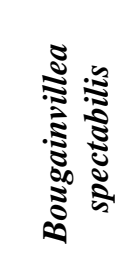 } \\
\hline & 호․ & $\stackrel{\infty}{\grave{2}}$ & ำ & $\stackrel{\infty}{\stackrel{2}{*}}$ & 츨 & 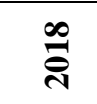 & ํํำ & $\stackrel{\infty}{\stackrel{2}{*}}$ & $\hat{\bar{ก}}$ & $\stackrel{\infty}{\stackrel{2}{*}}$ & 홍 & $\stackrel{\infty}{3}$ & 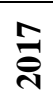 & $\stackrel{\infty}{\stackrel{2}{*}}$ \\
\hline $19^{\text {th }}-\mathrm{Feb}$ & 10 & 0 & 4 & 12 & 2 & 9 & 0 & 0 & 0 & 0 & 0 & 0 & 0 & 0 \\
\hline $29^{\text {th }}-\mathrm{Feb}$ & 18 & 0 & 14 & 19 & 7 & 6 & 0 & 0 & 0 & 0 & 0 & 0 & 0 & 0 \\
\hline $6^{\text {th }}-$ Mar & 8 & 7 & 102 & 38 & 12 & 8 & 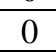 & 0 & 0 & 0 & 0 & 0 & 0 & 0 \\
\hline $13^{\text {th }} \mathrm{Mar}$ & 36 & 22 & 174 & 156 & 22 & 6 & 0 & 0 & 0 & 0 & 0 & 0 & 0 & 0 \\
\hline $20^{\text {th }} \mathrm{Mar}$ & 44 & 36 & 204 & 142 & 18 & 18 & 0 & 0 & 0 & 0 & 0 & 0 & 0 & 0 \\
\hline $26^{\text {th }} \mathrm{Mar}$ & 32 & 39 & 150 & 189 & 22 & 16 & 0 & 0 & 0 & 0 & 0 & 0 & 0 & 0 \\
\hline $3^{\text {rd }} \mathrm{Apr}$ & 16 & 41 & 248 & 220 & 18 & 12 & 0 & 0 & 0 & 0 & 0 & 0 & 0 & 0 \\
\hline $10^{\text {th }} \mathrm{Apr}$ & 12 & 17 & 264 & 263 & 22 & 11 & 0 & 0 & 0 & 0 & 0 & 0 & 0 & 0 \\
\hline $17^{\text {th }} \mathrm{Apr}$ & 24 & 16 & 398 & 349 & 29 & 10 & 0 & 0 & 0 & 0 & 0 & 0 & 0 & 0 \\
\hline $24^{\text {th }} \mathrm{Apr}$ & 10 & 19 & 464 & 321 & 8 & 26 & 0 & 0 & 0 & 0 & 0 & 0 & 0 & 0 \\
\hline $1^{\text {st }}$ May & 2 & 21 & 586 & 319 & 38 & 28 & 0 & 0 & 0 & 0 & 0 & 0 & 0 & 0 \\
\hline $8^{\text {th }}$ May & 22 & 15 & 180 & 356 & 44 & 35 & 0 & 0 & 0 & 0 & 0 & 0 & 0 & 0 \\
\hline $15^{\text {th }}$ May & 32 & 9 & 284 & 239 & 16 & 32 & 0 & 0 & 0 & 0 & 0 & 0 & 0 & 0 \\
\hline $22^{\text {nd }}$ May & 170 & 36 & 498 & 269 & 12 & 25 & 0 & 0 & 0 & 0 & 0 & 0 & 0 & 0 \\
\hline $29^{\text {th }}$ May & 66 & 96 & 144 & 415 & 39 & 29 & 0 & 0 & 0 & 0 & 0 & 0 & 0 & 0 \\
\hline $5^{\text {th }}$ June & 12 & 61 & 266 & 516 & 12 & 31 & 0 & 0 & 0 & 0 & 0 & 0 & 0 & 0 \\
\hline $12^{\text {th }}$ June & 2 & 81 & 26 & 158 & 5 & 18 & 0 & 0 & 0 & 0 & 0 & 0 & 0 & 0 \\
\hline $19^{\text {th }}$ June & 4 & 26 & 26 & 38 & 0 & 12 & 0 & 0 & 0 & 0 & 0 & 0 & 0 & 0 \\
\hline $26^{\text {th }}$ June & 2 & 62 & 0 & 65 & 0 & 19 & 0 & 0 & 0 & 0 & 0 & 0 & 0 & 0 \\
\hline Mean & 18.6b & $21.5 b$ & $144 a$ & 145.8a & $11.6 c$ & $12.5 \mathrm{c}$ & $\mathbf{0}$ & $\mathbf{0}$ & 0 & $\mathbf{0}$ & 0 & $\mathbf{0}$ & 0 & o \\
\hline
\end{tabular}

infested ornamental plants could be arranged descending according to infestation susceptibility as Tecoma stans, Rosa damascena, and Jasminum grandiflorum.

Obtained results demonstrated highest densities during 2017 season, it may because of the environmental factors. Lebbal and Laamari (2015) showed variability of infestation degree by aphids on different plants between years.

Previous results are congruent with Abd ElHadi (2002) who found that the highest population of Aphis gossypii on Salivia splendens flowers in Egypt at the third week of March. Also Ahmed (1990) observed A. gossypii began to appear on some medicinal and ornamental plants around the $3^{\text {rd }}$ week of June. Ullah et al (2014) in southern Punjab stated that aphid infestation started in the beginning of January and increased gradually to reach a peak at the end of
March, while the population started to decrease during June. Chapin et al (2001) recorded highest population during December and January in Florida state. Iinfestation is fluctuated according to weather factors which effects on aphid development during different seasons and planting date. Early planted crops recorded low densities (Shonga and Getu 2020). Patra et al (2012) reported same results, that recorded less aphid infestation on early planted season than late planted season depending on weather factor changes.

\subsection{The relation between leaf biochemical compo- nents and aphid infestation}

\subsubsection{Effect of Nitrogen, Phosphorus and Potassium}

Plant minerals play an important role on the growth insects. They obtained needed minerals from plants by feeding. Nitrogen, phosphorus, and 
potassium are classified as primary macronutrients. Data obtained in Table 2 showed positive significant between the aphid population and the nitrogen level. Nitrogen is considered very important required mineral for the growth of insect (Rostami et al 2012).

Phosphorus and potassium levels are related to aphid infestation that may cause resistance or susceptibility of plant. Phosphorus contributes to decreasing the host suitability to insect pests by changing secondary metabolites such as phenolics and terpenes. Increasing phenolics (tannin, lignin) acts as antifeedant or toxic substances that effects negatively on insect presence (Facknath and Lalljee 2005).

Increasing the Phosphorus treatment reduced the population of mustard aphid. Population decreased significantly with increase in rate of application, while increasing the phosphorous level led to increase the response of another insect pest such as Empoasca sp. and Frankliniella occidentalis (Bala et al 2018). They demonstrated also high levels of potassium help in plant resistance where it has negative significant on the building up of aphid populations. High levels of potassium help in plant resistance that enhance secondary compound metabolism and reduce the accumulation of carbohydrate that protect plant from pest attacking.

3.2.2 The activity of Antioxidant Defense Enzymes, Glutathione S-transferase (GST) and Superoxide dismutase activities (SODs)

Infestation by aphid causes increasing the activity of GSTs ad SODs in flag leaves in all the test ornamental plants as showed in Table 2. They recorded highly significant correlation with aphid infestation where $r$ values $=0.8420$ and 0.9332 , respectively. GST activity was determined to be highly increased in infested leaf plants than the uninfected leaf plant samples. Highly significant increase was observed in Tecoma stans followed by Rosa damascena and Jasminum grandiflorum. It recorded lowest levels in the uninfected plants, schefflera actinophylla, Nerium oleander and Bougainvillea spectabilis.

SOD activity was observed with the highest activity also in the infested leaf samples of tested ornamental plants. Maximum SOD activity was observed in infested leaves Tecoma stans compared to un-infested leaves, schefflera actinophylla, Nerium oleander and Bougainvillea spectabilis. Antioxidant Defense Enzymes are considered the first line defense protecting from the destructive activity occurred by Reactive Oxygen Species (ROS). Desingh and Kanagaraj (2007) supported the increasing in GST and SOD activities under salt stress condition in cotton plants may be due to feeding insect effect. The activity of antioxidant enzymes may help plants in facing environmental factor stresses (Mishra et al 2010). Simova-Stoilova et al (2009) recorded high activity of SOD in wheat plant because of environmental stress. Plant has enzymes act as antioxidant defense system including peroxidase, catalase, Glutathione S-transferase and superoxide dismutase enzymes, these enzymes protect plant from oxidative damage (Jaleel et al 2008).

Antioxidant enzymes are acting as destruction component for the damage caused by free radicals before oxidizing cell components. It may disrupt the oxidizing process caused by free radicals to reduce the damage as possible. Glutathione S-transferase detoxifying the toxic substance by conjugation with glutathione that led to reducing oxidative stress. Superoxide dismutase is responsible for inhibit the reactive of superoxide anion to oxygen then reducing reactive species Hydrogen peroxide.

\subsubsection{Total carbohydrates}

There is negative correlation between the infestation level and the amount of total carbohydrates where ( $\mathrm{r}$ value $=-0.5858)$. Zou and Cates (1994) added 6\% mount of galactose in artificial diet to feed western spruce budworm, that interrupt larval growth and caused incomplete stage. Rani and Jyothsna (2010) reported that the increased levels of carbohydrates in rice plants suggest their role in the plant's defense mechanism by inducing the signaling pathways. Obtained results were enhanced with the finding of Helmi and Rashwan (2015), they investigated negative correlation between sap sucking insect infestation and total soluble sugars content in tomato cultivars, where it recorded highest levels in the resistant plants.

\subsection{Effect of morphological features of ornamental plants on aphid infestation}

Plant uses trichomes as a line defense against phloem feeders such as hemipters insects which considered a vital role in plan protection (Wagner et al 2004). As shown in Fig 1, scanning electron microscope of seven ornamental plants, trichomes play an important role in aphid infestation. Three ornamental plants Rosa damascena, Tecoma stans and Jasminum grandiflorum showed no trichomes on their lower surface while Ruta graveolens and Nerium oleander. Large intensity 


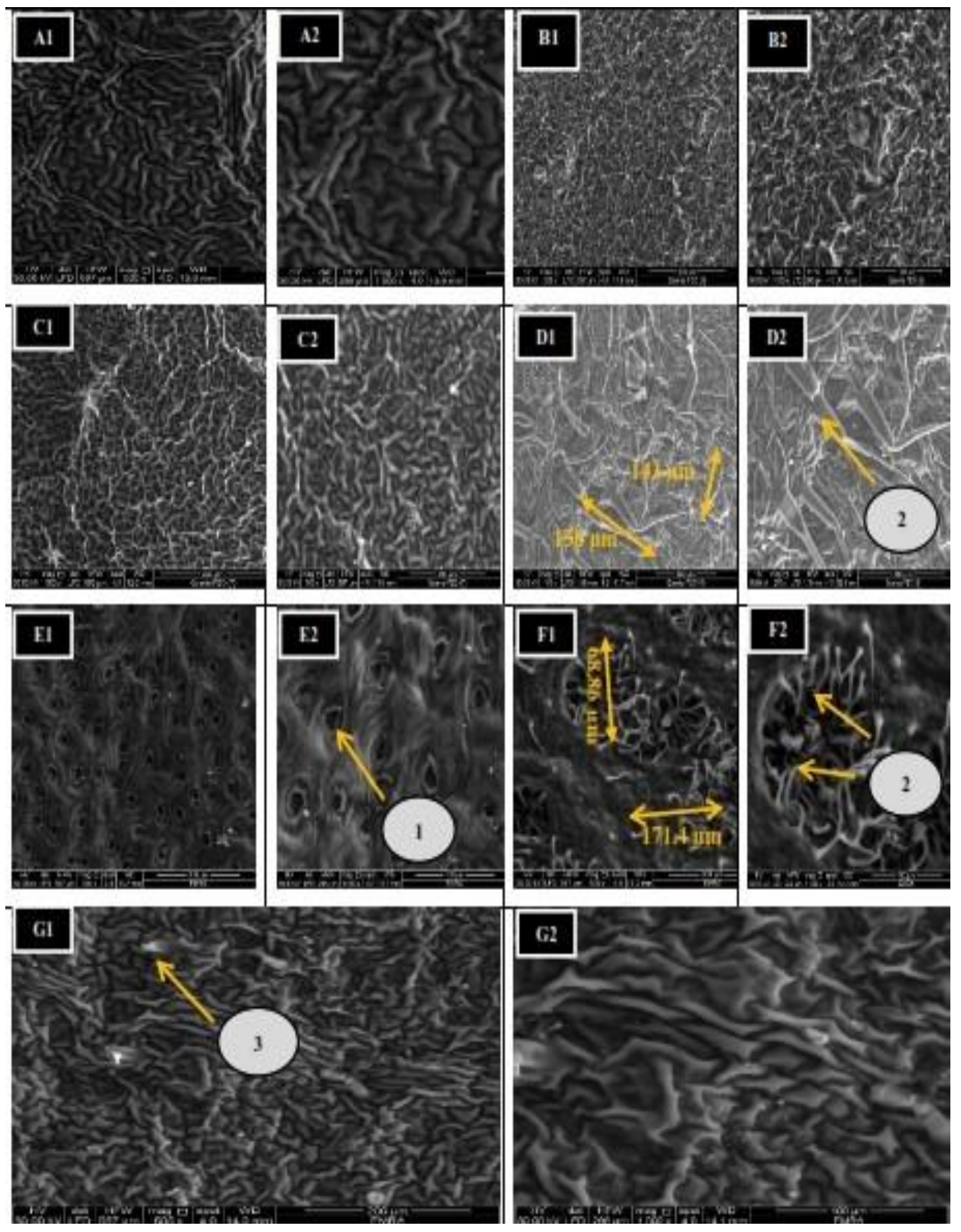

Fig 1. Scanning electron microscope of the lower surface of seven types of ornamental plants with two magnification powers (500x and 1000x). A: Rosa damascena B: Tecoma stans C: Jasminum grandiflorum D: Ruta graveolens E: schefflera actinophylla F: Nerium oleander G: Bougainvillea spectabilis.

1: Stomata opening, 2: non-glandular trichomes, 3: Glandular trichomes 
of trichomes were observed on the lower surface that interrupt biological activities and keep plant free from infestation. These trichomes are varied in length and density. These structures may prevent insect feeding on the sap plant, leaf surface of plant has fundamental effect on the insect behavior. The finding of these results showed congruity with Amin et al (2017) who demonstrated negative correlation between leaf trichomes of cotton verities and aphid abundance, while nonsignificant correlation was recorded with jassid population.

Schefflera actinophylla showed high number of stomata. Nevertheless, Li et al (2011), Coll and Hughes (2008) recorded high densities of aphid infestation on plants that have large number of stomata. Elevating high amount of carbon dioxide might be increase insect attacking to plants. Repellent effective of $S$. actinophylla may be due to the biochemical component of plant leaf. Scanning electron microscope of Bougainvillea spectabilis showed glandular trichomes may play as defense effect against insect feeding. These results showed close conformity with Helmi and Mohamed (2016) who recorded highly negative significant relationship between glandular trichomes and aphid infestation on tomato cultivars. It could be conducted that tomato plants have high densities of glandular and non-glandular trichomes on leaf surface that prevent attacking and feeding of many insect pests (Tian et al 2012). Price et al (2011) demonstrated that feeding by insects is interrupted because of long and dense of soyabean trichomes on the leaf surface. Morphological characters and biochemical components have an important role in plant resistance (Gameel 2014).

\subsubsection{Proline}

The obtained results in the Table 2, demonstrated that increasing insect density on plants led to increase of proline content. As shown, the highest amount of proline was observed in Tecoma stans which has the highest infestation. Highly positive correlation was observed between proline and infested plants, where the calculated value $(r=0.9530)$. Hayat et al (2012) agreed with the finding, where they stated positive correlation between accumulation of proline and plant stress. It may be suggested proline act as antioxidant Reactive Oxygen Species scavenger (Matysik et al 2002).

\subsubsection{Tannins}

The content of tannins increased in the un-infested leaf sample plants as shown in Table 2, where $r$ value $=-0.6672$. The highest activity of tannins was recorded in un-infested leaf samples Increasing tannins content indicates their protective role as antioxidant defense against biotic and abiotic effects. Tannins have the capacity to interact with proteins suggesting that tannins affected insect herbivores by inactivating insect enzymes as well as dietary proteins that might be indicated the role of tannins as feeding (Robbins et al 1987). An increasing in the amount of total tannins indicated that tannins might play a role as feeding inhibition (Grayer et al 1992). Bernays (2008) reported that accumulate tannins in leaves protect plant from insect survival as they rapid proteins nonspecifically by covalent bonding or hydrogen bonding with proteins, that may reduce the mineralization of nitrogen or digestion process.

\subsubsection{Total phenols and Phenol oxidase}

The highest amount of phenols and Phenol oxidase were found in the un-infested ornamental plant (schefflera actinophylla, Nerium oleander and Bougainvillea spectabilis). These results are in accordance with Perveen et al (2001), they demonstrated higher phenolic content in susceptible cotton plant varieties than resistant ones. Xu et al (2021) stated that phenols are secondary compounds in plants enhance resistance wheat against aphid attack. Resistance wheat cultivars synthesize higher enzymes and stimuli producing more tannins and phenols than susceptible ones.

The elevation of phenols could be explained as a mechanism of defense against insect feeding. Plant phenols produce toxic secondary metabolites which causes toxicity for herbivores (Helmi and Mohamed 2016), these phenolic compounds are known to inhibit insect development.

Phenol oxidations produce quinones that may inhibit digesting protein in insects (Bhonwonget al 2009).

\subsubsection{Total protein and total free amino acids}

Results in Table 2 indicated that total proteins and total free amino acids in leaves of the un-infested plants (schefflera actinophylla, Nerium) is lower than in the susceptible plant (Tecoma stans). When plants expose to ultra-stress, they may produce extra amounts of biochemical components and secondary 
Table 2. Biochemical analysis of some components of seven ornamental plants and its relation to aphid infestation

\begin{tabular}{|c|c|c|c|c|c|c|c|c|}
\hline \multirow[b]{2}{*}{$\begin{array}{l}\text { Biochemical } \\
\text { components }\end{array}$} & \multicolumn{7}{|c|}{ Ornamental plants } & \multirow{2}{*}{ Correlation (r) } \\
\hline & 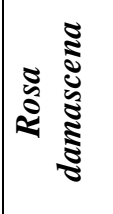 & 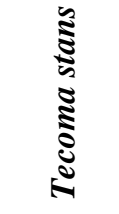 & 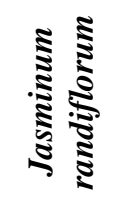 & 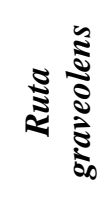 & 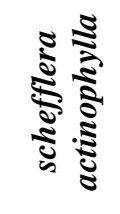 & 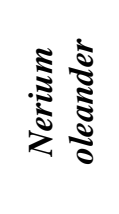 & 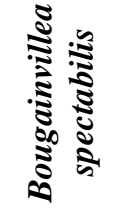 & \\
\hline Aphid population & 20 & 144.9 & 12 & 0 & 0 & 0 & 0 & ----- \\
\hline $\begin{array}{c}\text { Nitrogen } \\
(\mathrm{ug} / \mathrm{gm})\end{array}$ & 2098 & 1187.3 & 3984.3 & 2021.3 & 2144.6 & 2526.6 & 1756.6 & 0.4288 \\
\hline $\begin{array}{c}\text { Phosphorus } \\
\text { (ug/gm) }\end{array}$ & 225.3 & 200.3 & 451.6 & 354 & 427.6 & 386.6 & 262.3 & -0.6309 \\
\hline $\begin{array}{l}\text { Potassium } \\
(\text { uEq/gm) }\end{array}$ & 52 & 26.4 & 1.6 & 44.9 & 29.2 & 50.9 & 49.2 & -0.5455 \\
\hline $\begin{array}{c}\text { GST } \\
\text { (mmolesub. } \\
\text { conjugated/min/gm) }\end{array}$ & 18.6 & 20.7 & 11.2 & 8.3 & 9.2 & 10.1 & 9.7 & 0.8420 \\
\hline $\begin{array}{c}\text { Superoxide dismutase } \\
\text { (SOD }\end{array}$ & 98 & 117.2 & 76 & 86 & 77.3 & 82.6 & 56.3 & 0.9332 \\
\hline $\begin{array}{c}\text { Proline } \\
\text { ug proline/gm }\end{array}$ & 291 & 634.3 & 198 & 90 & 156.3 & 100.3 & 45.6 & 0.9530 \\
\hline $\begin{array}{c}\text { Tannins } \\
\text { ug tannic acid/gm }\end{array}$ & 128 & 92.3 & 117.6 & 129.3 & 102.3 & 115.3 & 186.6 & -0.6672 \\
\hline $\begin{array}{c}\text { Total phenols } \\
\text { (ug GAE/gm }\end{array}$ & 796 & 559.3 & 777.3 & 783 & 856.3 & 615 & 751.3 & -0.6527 \\
\hline $\begin{array}{l}\text { Phenol oxidase } \\
\text { (O.D. units/min/gm }\end{array}$ & 5.1 & 3.2 & 3.2 & 5.8 & 13.8 & 13.2 & 25.2 & -0.5917 \\
\hline $\begin{array}{l}\text { Total proteins } \\
\mathrm{mg} / \mathrm{gm}\end{array}$ & 12.6 & 7.3 & 22.6 & 6.4 & 12.6 & 16.3 & 11.6 & 0.2794 \\
\hline $\begin{array}{c}\text { Free amino acids } \\
\text { (ug D,L-alanine/gm) }\end{array}$ & 511 & 942 & 430 & 850 & 1018.6 & 853 & 613.3 & 0.3136 \\
\hline $\begin{array}{l}\text { Total carbohydrates } \\
(\mathrm{mg} / \mathrm{gm})\end{array}$ & 11.9 & 12.7 & 27.1 & 10.9 & 29.1 & 28.1 & 38.9 & -.5858 \\
\hline
\end{tabular}

metabolites that affect on insect activity such as feeding, oviposition, digestion, reproductive. These results are congruent with the finding of Rani and Pratyusha (2013) who recorded the highest level of proteins in the infested plant than un-infested plant. Mohamed and Abd-El Hameed (2014) investigated that increasing protein level may because of defense after the infestation of stored insect. Amino acids are demonstrated as a product of metabolites that work as a defense line in infested plant (War et al 2012). Alkylation of amino acids may change the value of plant nutrition that prevent growth and development of insect (Bhonwong et al 2009).

\section{Conclusion}

Seven ornamental plants showed different susceptibility to aphid infestation. Biochemical components activities varied between sensitive and resistance plants. Moreover, morphological structure of plant leaves such as stomata, glandular and non-glandular trichomes play an important role in plant sensitivity. Resistance plants showed higher densities of trichomes on leaf surface than in susceptible ones. Resistant plants could be recommended in the integrated pest management programs to avoid using extra chemical insecticides. 


\section{Arab Univ J Agric Sci (2021) 29 (3) 913-923}

\section{References}

Abd El-Hadi AS (2002) Ecological and biological studies on Homopterous insects infesting some ornamental plants. M.Sc. Thesis, Faculty of Agriculture, Al-Azhar University, Egypt.119 pp.

Ahmed MT (1990) Studies on some insect pests infesting certain medicinal plants. Ph. D. Thesis Faculty of Agriculture, Al-Azhar University, Egypt 148 pp.

Amin MR, Afrin R, Alam MZ, Hossain MM, Kwon YJ (2017) Effect of Leaf Trichomes and Meteorological Parameters on Population Dynamics of Aphid and Jassid in Cotton. Bangladesh Journal of Agricultural Research. 42, 13-25. https://doi.org/10.3329/bjar.v42i1.31969

Bala K, Sood AK, Pathania VS, Thakur S (2018) Effect of plant nutrition in insect pest management: A review. Journal of Pharmacognosy and Phytochemistry 7, 2737-2742.

Bernays E (2008) Plant tannins and insect herbivores: An appraisal. Ecological Entomology 6, 353-360.

DOI:10.1111/j.1365-2311.1981.tb00625.x

Bhonwong A, Stout MJ, Attajarusit J, Tantasawat P (2009) Defensive role of tomato polyphenol oxidase against cotton bollworm (Helicoverpa armigera) and beet armyworm (Spodoptera exigua). Journal of Chemical Ecology 35, 28-38. https://doi.org/10.1007/s10886-008-9571-7

Boctor FN (1971) An improved method for colorimetric determination of proline with isatin. Analytical Biochemistry 43, 66-70.

DOI:10.1016/0003-2697(71)90108-4

Bradford MM (1976) A rapid and sensitive method for the quantitation of microgram quantities of protein utilizing the principle of protein-dye binding. Analytical Biochemistry 72, 248-254.

https://doi:10.1006/abio.1976.9999

Brzozowski LJ, Mazourek M (2020) Evaluation of Selection Methods for Resistance to a Specialist Insect Pest of Squash (Cucurbita pepo). Agronomy 10,847 .

https://doi.org/10.3390/agronomy 10060847

Chapin JW, Thomas JS, Gray SM, Smith DM, Halbert SE (2001) Seasonal Abundance of Aphids (Homoptera: Aphididae) in Wheat and Their Role as Barley Yellow Dwarf Virus Vectors in the South Carolina Coastal Plain. Journal of Economic Entomology 94, 410-421. https://doi.org/10.1603/0022-0493-94.2.410

Coll M, Hughes L (2008) Effects of elevated CO2 on an insect omnivore: a test for nutritional effects mediated by host plants and prey. Agriculture, Ecosystems \& Environment 123, 271-279.

https://doi.org/10.1016/j.agee.2007.06.003

Crompton M, Birt LM (1967) Changes in the amounts of carbohydrates, phosphagen and related compounds during the metamorphosis of the blowfly, Luciliacuprina. Journal of Insect Physiology 13, 1575-1592.

https://doi.org/10.1016/0022-1910(67)90180-1

Dean J V, Devarenne T P, Lee I, Orlofsky L E (1995). Properties of a Maize Clutathione S-Transferase That Conjugates Coumaric Acid and Other Phenyl propanoids. Plant Physiol, 108, 985-994.

DOI:10.1104/pp.108.3.985

Desingh R, Kanagaraj G (2007) Influence of salinity stress on photosynthesis and antioxidative systems in two cotton varieties. General and Applied Plant Physiology 3, 221- 234.

Dubois M, Gilles KA, Hamilton JK, Rebers PA, Smith F (1956) Colorimetric method for determination of sugars and related substances. Analytical Chemistry 28, 350-356. https://doi.org/10.1021/ac60111a017

Echlin P (2009) Handbook of sample preparation for scanning electron microscopy and X-ray microanalysis. Springer New York 332 pp.

DOI: 10.1007/978-0-387-85731-2

Facknath S, Lalljee B (2005) Effect of soil-applied complex fertilizer on an insect-host plant relationship: Liriomyza trifolii on Solanum tuberosum. Entomologia Experimentalis et Applicata 15, 67-77.

DOI:10.1111/j.1570-7458.2005.00288.x

Gameel SM (2014) Effect of planting date on seasonal abundance of the Aphis craccivora koch and the associated predators in the new Valley-Egypt. Egyptian Academic Journal of Biological Sciences 7, 97-103. https://eajbsa.journals.ekb.eg/article_13141.html

Grayer RJ, Kimmins FM, Padgham DE, Harborne JB, Ranga Rao DV (1992) Condensed tannin levels and resistance in groundnuts (Arachis hypogoea L.) against Aphis craccivora (Koch). Phytochemistry 31, 3795-3799.

https://doi.org/10.1016/S0031-9422(00)97530-7

Hanley ME, Lamont BB, Fairbanks MM, Rafferty CM (2007) Plant structural traits and their role in antiherbivore defense. Perspectives in Plant Ecology, Evolution and Systematics 8, 157-178.

https://doi.org/10.1016/j.ppees.2007.01.001 
Hayat S, Hayat Q, Alyemeni MN, Wani AS, Pichtel J, Ahmad A (2012) Role of proline under changing environments. Plant Signaling \& Behavior 7, 1456-1466. DOI:10.4161/psb.21949

Helmi A, Mohamed HI (2016) Biochemical and ultrastructural changes of some tomato cultivars after infestation with Aphis gossypii Glover (Hemiptera: Aphididae) at Qalyubiyah, Egypt. Gesunde Pflanzen 68, 41-50.

https://doi.org/10.1007/s10343-016-0361-9

Helmi A, Rashwan RS (2015) Susceptibility of Some Solanaceous Plant Cultivars to Sap-Sucking Insects Infestation and their Associated Natural Enemies. Journal of Plant Protection and Pathology 6, 763-781.

Jaleel CA, Jayakumar K, Chang-Xing Z, Azooz MM (2008) Effect of soil applied cobalt on activities of antioxidant enzymes in Arachis hypogaea. Global Journal of Molecular Sciences 3, 42-45.

Kâhkônen MP, Hopia AI, Vuorela KJ, Rauha JP, Pihlaja K, Kujala TS, Heinonen M (1999) Antioxidant activity of plant extracts containing phenolic compounds. Journal of Agricultural and Food Chemistry 47, 3954-62.

https://doi.org/10.1021/jf9901461

Kelley OJ, Hunter AS, Sterges AJ (1946). Determination of Nitrogen, Phosphorus, Potassium, Calcium, and Magnesium in Plant Tissue. Semimicro Wet-Digestion Method for Large Numbers of Samples. Industrial \& engineering chemistry Analytical Edition. Ed., 319-322.

https://doi.org/10.1021/i560153a018

Khatab H (2007) The Defense Mechanism of Cabbage Plant Against Phloem-Sucking Aphid (Brevicoryne brassicae L.). Australian Journal of Basic and Applied Sciences 1, 56-62.

Lebbal S, Laamari M (2015) Seasonal dynamics of aphids on lemon (Citrus limon (L.) Burm. f.), orange (C. sinensis (L.) Osb.) and Clementine (C. clementina Hort. ex Tan.) in Skikda (Algeria). Journal of Entomology and Zoology 3, 321-324.

Lee YP, Takabashi T (1966) An improved colorimrtric determination of amino acids with the use of ninhydrin. Analytical Biochemistry 14, 71-77. https://doi.org/10.1016/0003-2697(66)90057-1

Li Z, Liu T, Xiao N, Li J, Chen F (2011) Effects of elevated $\mathrm{CO} 2$ on the interspecific competition between two sympatric species of Aphis gossypii and Bemisiatabaci fed on transgenic Bt cotton. Insect Science 18, 426-434.

https://doi.org/10.1111/j.1744-7917.2011.01433.x

Marrs KA, Alfenito MR, Lloyd AM, Walbot (1995) A glutathione S-transferase involved in vacuolar transfer encoded by the maize gene Bronze-2. Nature 375, 397-400. DOI:10.1038/375397a0.

Matysik J, Alia, Bhalu B, Mohanty P (2002) Molecular mechanisms of quenching of reactive oxygen species by proline under stress in plants. Current Science 82, 525-532.

https://www.jstor.org/stable/24105959?seq=1

Mccord JM, Fridovich I (1969) Superoxide dismutase, an enzymatic function for erythrocuprein (hemocuprein). Journal of Biological Chemistry 244, 6048-6055. https://pubmed.ncbi.nlm.nih.gov/5389100/

Mehrparvar M, Mobli M, Hatami B (2008) Seasonal Population Fluctuations of the Rose Aphid, Macrosiphum rosae (L.) (Hemiptera: Aphididae), on Different Cultivars of Roses and Nastaran. Journal of Crop Production and Processing 12, 711-718.

http://jstnar.iut.ac.ir/article-1-954-en.html

Mishra S, Jha AB, Dubey RS (2010) Arsenite treatment induces oxidative stress, upregulates antioxidant system, and causes phytochelatin synthesis in rice seedlings. Protoplasma 248, 565-577.

https://doi.org/10.1007/s00709-010-0210-0

Mohamed HI, Abd-El Hameed AG (2014) Molecular and biochemical markers of some Vicia faba L. genotypes in response to storage insect pest's infestation. Journal of Plant Interactions 9, 618-626. DOI:10.1080/17429145.2013.879678

Moore S, Stein WH (1948) Photometris Ninhydrin Method for Use in the Chromatography of Amino Acids. Journal of Biological Chemistry 176, 367-388.

Ni X, Quisenberry SS, Heng-Moss T, Markwell J, Sarath G, Klucas R, Baxendale F (2001) Oxidative responses of resistant and susceptible cereal leaves to symptomatic and non-symptomatic cereal aphid (Hemiptera: Aphididae) feeding. Journal of Economic Entomology 94, 743-751.

DOI:10.1603/0022-0493-94.3.743

Patra S, Thakur NSA, Saikia K, Firake DM (2012) Population dynamics of cabbage aphid, Brevicoryne brassicae L. on major cole crops in Meghalaya. Madras Agricultural Journal 99, 573-575. 
Perveen SS, Qaisrani TM, Amin S, Perveen R, Nagvi SHM (2001) Biochemical basis of insect resistance in cotton. Journal of Biological Sciences 1, 496-500. DOI:10.3923/jbs.2001.496.500

Price PW, Denno RF, Eubanks MD, Finke DL, Kaplan I (2011) Behavior, populations, and communities in Insect Ecology: 816 pp. Cambridge University Press, UK.

https://doi.org/10.1111/j.1570-7458.2012.01294.x

Rani PU, J yothsna Y (2010) Biochemical and enzymatic changes in rice as a mechanism of defense. Acta Physiologiae Plantarum 32, 695-701. https://doi.org/10.1007/s11738-009-0449-2

Rani PU, Pratyusha S (2013) Defensive role of Gossypium hirsutum L. anti-oxidative enzymes and phenolic acids in response to Spodoptera lituralis $\mathrm{F}$. feeding. Journal of Asia-Pacific Entomology 16, 131-136. DOI:10.1016/j.aspen.2013.01.001

Rashwan RS, Alghamdi AS, Althagafi SS (2016) Morphological Identification of Aphid Species Infesting Some Ornamental plants in Taif Governorate. Egyptian Academic Journal of Biological Sciences 9, 15-35.

DOI:10.21608/EAJBSA.2016.12744

Robbins CT, Hanley TA, Hagerman AE, Hjeljord O, Baker DL, Schwartz CC, Mautz WW (1987) Role of tannins in defending plants against ruminants: reduction in protein availability. Ecology 68, 98-107. https://doi.org/10.2307/1938809

Rockstein M, Herron PW (1951) Colorimetric determination of inorganic phosphate in microgram quantities. Analytical Chemistry 23, 1500-1501. https://doi.org/10.1021/ac60058a044

Rostami M, Zamani AA, Goldastech S, Shoushtari RV, Kheradmand K (2012) Influence of nitrogen fertilization on biology of Aphis gossypii (Hemiptera: Aphididae) Reared on Chrysanthemum Iindicum (Asteraceae). Journal of Plant Protection Research 52, 118-121.

https://doi.org/10.2478/v10045-012-0019-2

Sadasivam S, Manickam A (1992) Biochemical methods for agricultural sciences. New Delhi Wiley Eastern Ltd pp 187-188.

SAS (2001) User's Guide. SAS Institute, Cary, NC.

Shonga E, Getu E (2020) Population dynamics of cabbage aphid, Brevicoryne brassicae L. (Homoptera: Aphididae) in relation to weather factors on major brassica crops in central rift valley of Ethiopia: baseline studies for the management of the pest. International Journal of Tropical Insect Science, https://pubag.nal.usda.gov/catalog/7286579

Simova L, Demirevska K, Petrova T, Tsenov N, Feller U (2009) Antioxidative protection and proteolytic activity in tolerant and sensitive wheat (Triticum aestivum L.) varieties subjected to long-term field drought. Plant Growth Regulation 58,107-117.

DOI:10.1007/s10725-008-9356-6

Tian D, Tooker J, Peiffer M, Chung SH, Felton GW (2012) Role of trichomes in defense against herbivores: comparison of herbivore response to woolly and hairless trichome mutants in tomato (Solanum lycopersicum). Planta 236, 1053-1066.

https://doi.org/10.1007/s00425-012-1651-9

Torres MA (2010) ROS in biotic interactions. Physiologia Plantarum 138, 414-429.

https://doi.org/10.1111/j.1399-3054.2009.01326.x

Ullah S, Bibi R, Amjad Bashir M, Ibrahim M (2014) Population Dynamics of Aphid and its Bio-Control Agents in Wheat Crop. Pakistan Journal of Nutrition 13, 146-150. DOI:10.3923/pjn.2014.146.150

Vartainan N, Hervochon P, Marcotte L, Larher F (1992) Proline accumulation during drought rhizogenesis in Brassica napus var. Oleifera Plant Physiology 140, 623-628.

http://dx.doi.org/10.1016/S0176-1617(11)80799-6

Wagner, GJ, Wang E, Shepherd RW (2004) New approaches for studying and exploiting an old protuberance, the plant trichome. Annals of Botany 93, 3-11.

DOI:10.1093/aob/mch011

War AR, Paulraj MG, Ahmad T, Buhroo AA, Hussain B, Ignacimuthu S, Sharma HC (2012) Mechanisms of plant defense against insect herbivores. Plant Signaling \& Behavior 7, 1306-1320.

https://doi.org/10.4161/psb.21663

Xu Y, Guo H, Geng G, Zhang O, Zhang Q (2021) Changes in defense related enzymes and phenolics in resistant and susceptible common wheat cultivars under aphid stress. Acta Physiologiae Plantarum 43, 36 doi.org/10.1007/s11738-021-03207-3

Zou JP, Cates RG (1994) Role of Douglas-fir (Pseudotsuga menziesii) carbohydrates in resistance to budworm (Choristoneura occidentalis). Journal of Chemical Ecology 20, 395-405. https://doi.org/10.1007/BF02064446 